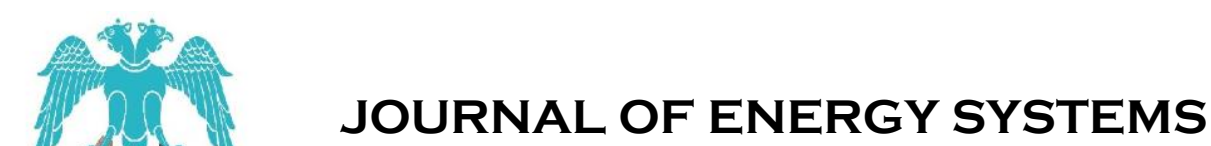

Volume 1, Issue 3

DOI: $10.30521 /$ jes.355507

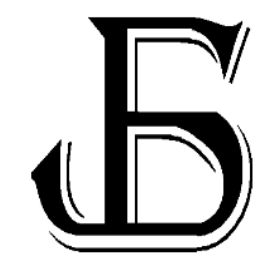

Research Article

\title{
Properties of the $\mathrm{CdS}_{\mathrm{x}} \mathrm{Te}_{1-\mathrm{x}}$ solid solution: As a single product and as a part of the CdS/CdTe solar cell
}

\author{
Shadia J. Ikhmayies \\ Al Isra University, Faculty of Science, Department of Physics, Amman, 11622, Jordan, \\ shadia_ikhmayies@yahoo.com, orcid.org/0000-0002-2684-3300 \\ Arrived: 18.11.2017 Accepted: 09.12.2017 Published: 11.12.2017
}

\begin{abstract}
Thin film CdS/CdTe solar cells are promising candidates for large-scale photovoltaics. The $\mathrm{CdS}_{\mathrm{x}} \mathrm{Te}_{1-\mathrm{x}}$ solid solution is always formed at the interface between the CdS window layer and $\mathrm{CdTe}$ absorber layer due to the intermixing at the interface region. It is confirmed that this interdiffusion process significantly affects the device performance. This occurs through several things of which are changing the bandgap of both CdTe and CdS, which modifies the spectral response of the solar cell, and reducing the lattice mismatch at the CdS/CdTe junction which results in the reduction of the number of interfacial states and recombination centers. This work gives a short review of the properties of this solid solution in two cases; first, when it is produced as a separate product (i.e. powder or thin films), and second when it is part of the solar cell (i.e. created due to interdiffusion or introduced as a layer between $\mathrm{CdS}$ and $\mathrm{CdTe}$ ).
\end{abstract}

\begin{tabular}{cc}
\hline Keywords: & CdS/CdTe solar cells, CdSxTe1-x solid solution, Interdiffusion, Bandgap, Thin films, \\
\hline \begin{tabular}{cc} 
Cite this & Ikhmayies, S.J. Properties of the CdSxTe1-x solid solution: As a single product and as a part of the \\
paper: & CdS/CdTe solar cell, Journal of Energy Systems 2017; 1(3): 102-110 DOI: 10.30521/jes.355507 \\
\hline
\end{tabular}
\end{tabular}

C 2017 Published by JES peer-review scientific journal at DergiPark (www.dergipark.gov.tr/jes) 


\section{INTRODUCTION}

Development of photovoltaic systems requires a reliable, efficient, and low cost technology. Thin film $\mathrm{CdTe} / \mathrm{CdS}$ photovoltaic devices satisfy these requirements [1]. Progress has been made in improving the efficiency of $\mathrm{CdTe} / \mathrm{CdS}$ research devices, where a final recorded efficiency of $22.1 \%$ has been obtained by Green et al. [2]. Light absorption and charge separation in thin-film polycrystalline cadmium telluride (CdTe) photovoltaic (PV) solar cells largely occur in the vicinity of the CdS/CdTe interface [3]. Alloying between CdS and CdTe at this interface to form CdSxTe1-x is important for efficient PV devices. This alloying is a function of the growth temperature and post deposition $\mathrm{CdCl} 2$ heat treatment (HT) [4], where the best device performance is obtained in cells prepared by high temperature processes. While, $\mathrm{CdCl} 2$ heat treatment enhances the crystal structure of the layers, reduces the density of defects in the transition region of the heterojunction, and forms CdSxTe1-x solid solution at the interface, which results in improving the performance of the solar cell.

The interdiffusion on the CdS/CdTe interface is bidirectional, but there is more sulfur diffusing into the CdTe than Te diffused into the CdS [5]. The solid solution formed in the CdTe side of the junction is Te-rich and it is referred to as CdSxTe1-x, where x refers to the concentration of S. On the other hand, the solid solution formed in the CdS side of the junction is S-rich, and it is referred to as CdS1-yTey, where y refers to the concentration of Te. A schematic of the superstrate CdS/CdTe thin film solar cell is illustrated in Fig.1, where the solid solution on both sides of the junction is shown. Light reaches the CdTe absorber layer through the glass substrate, transparent conductive oxide ( $\mathrm{SnO} 2)$, then the $\mathrm{CdS}$ window layer.

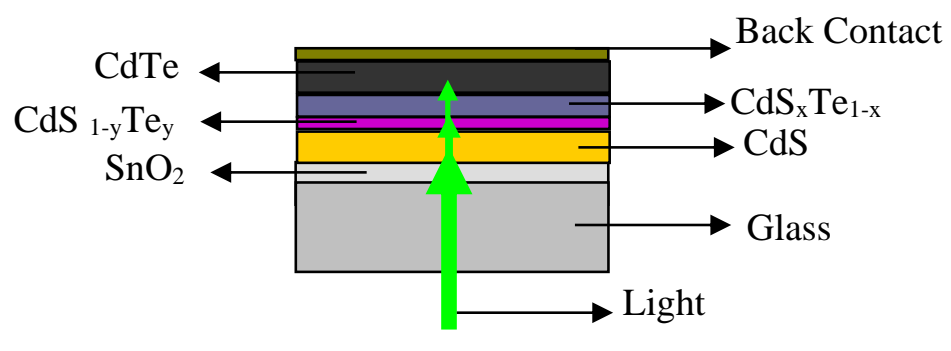

Figure 1. A schematic of the superstrate configuration of the $\mathrm{SnO}_{2} / \mathrm{CdS} / \mathrm{CdTe}$ thin film solar cell, where the solid solutions on both sides are shown. Note: Drawing is not to scale [6].

Polycrystalline CdSxTe1-x and CdS1-yTey thin films can be produced by several methods such as: thermal evaporation (co-evaporation of CdS and CdTe) [7-9], RF magnetron sputtering [9], brush plating [10], pulsed laser deposition [11], pulse plating [12], closed space sublimation [13-17], metal organic chemical vapor deposition MOCVD [18], chemical bath deposition (CBD) [19], and spray pyrolysis [20-22] by first producing CdS films then annealing in Te atmosphere. It is well known that the properties of produced films are affected by the deposition technique and deposition parameters used, such as deposition rate, substrate temperature, and thickness of the films [8].

Several authors $[5,8,10,12,13,20-22]$ produced and characterized CdSxTe1-x thin films, and others used computational methods to study the CdSxTe1-x solid solution [23], but there is a need to have a review about the production, properties, and significance of CdSxTe1-x solid solutions inside and outside the $\mathrm{CdS} / \mathrm{CdTe}$ solar cell. The aim of this work is to review the significance and some properties of this alloy when produced as a separate product and in the interfacial region of the CdS/CdTe thin film solar cell. 


\section{SOME PROPERTIES OF CdS $\mathrm{Ce}_{1-\mathrm{X}}$ AND $\mathrm{CDS}_{1-\mathrm{Y}} \mathrm{TE}_{\mathrm{Y}}$ SOLID SOLUTIONS}

Understanding the properties of the CdSxTe1-x and CdS1-yTey alloys is essential to improve the performance of CdS/CdTe thin film solar cells. A brief idea about some of the properties of these alloys will be given in the following paragraphs.

\section{Structural Properties}

The CdS-CdTe solid solutions can grow in the cubic (zinc blende) phase, the hexagonal (wurtzite) phase or the mixed (cubic and hexagonal) phase [6,7]. CdTe1-xSx has the crystallographic form of the zinc blende (ZB) with space group (F-43m) structure, and CdS1-yTey the wurtzite (WZ) structure with space group $(\mathrm{P} 63 \mathrm{mc})$. The mixed phase of the CdS-CdTe system shows a large miscibility gap that depends on temperature in which both phases (cubic and hexagonal) are present. Compaan and Bohn $[6,11]$ found that the miscibility gap of CdTe1-xSx spans the range between $\mathrm{x}=0.16$ to $\mathrm{x}=0.86$ at a temperature of $\mathrm{T}=650^{\circ} \mathrm{C}$, Duenow et al. [9] showed that it spans the range between $\mathrm{x}=0.058$ and $\mathrm{x}=$ 0.97 at a temperature of $415^{\circ} \mathrm{C}$. Single-phase films that exist within this gap are not in thermodynamic equilibrium, and hence, one should expect a large driving force for decomposition or phase separation in the material [11].

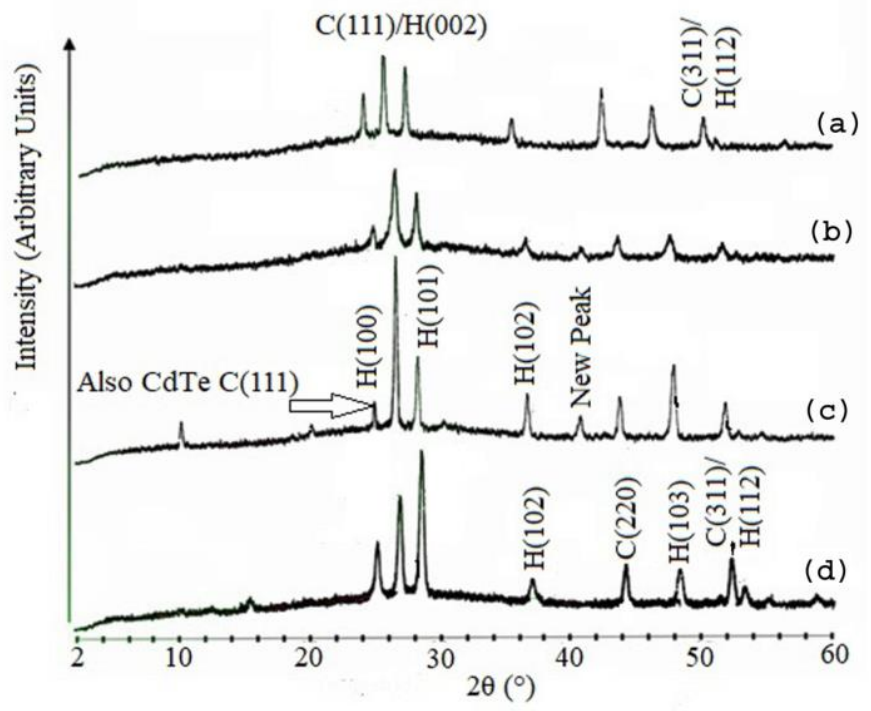

Figure 2. X-ray diffractograms of three $C d S_{1-y} T e_{y}$ with different Te content beside the diffractogram of asdepoited CdS:In film.

The lattice spacing and lattice parameters of the CdS-CdTe solid solutions vary with composition. Ikhmayies and Ahmad-Bitar produced polycrystalline $\mathrm{CdS}_{1-\mathrm{y}} \mathrm{Te}_{\mathrm{y}}$ thin films by first producing CdS:In thin films by the spray pyrolysis technique and then annealing the films in Te atmosphere [20,21]. The X-ray diffractograms of some of these films ( $a, b$ and c) beside that of pure CdS:In (d) are shown in Fig.2, where film (a) has the greatest Te content, and film (c) has the least Te content. The films display a polycrystalline mixed structure. Comparison between the diffractograms clearly shows a shift in the positions of all reflection peaks towards smaller angles with the increase in Te content. This indicates that the lattice spacing $d$ increases with the increase of Te content in the films. The same thing was observed by Murali and Thirumoorthy [24] for $\mathrm{CdS}_{\mathrm{x}} \mathrm{Te}_{1-\mathrm{x}}$ films prepared by pulse plating. In addition, the comparison between the diffractograms shows a new peak located at $2 \theta=40.8^{\circ}$ in the diffraction patterns of films (c) and (b) which is related to $\mathrm{CdS}_{1-\mathrm{y}} \mathrm{Te}_{\mathrm{y}}$ alloy. On the other hand, for the cubic Te rich 
$\mathrm{CdS}_{\mathrm{x}} \mathrm{Te}_{1-\mathrm{x}}$ alloy, Dhere, et al. [4] found that the (111) peak of CdTe in the XRD pattern shifts towards higher angles as the lattice constant of the alloy decreases with addition of $\mathrm{S}$.

The dependence of lattice spacing on composition enables obtaining the lattice parameter from X-ray diffraction measurements and hence calculating the mole fraction $(\mathrm{x})$ or $(\mathrm{y})$ for different phases of CdSCdTe solid solutions. According to Murali et al. [12] the variation of lattice spacing and lattice parameters with composition is linear and obeys Vegard's law [9], where the lattice parameters of $\mathrm{CdS}_{\mathrm{x}} \mathrm{Te}_{1-\mathrm{x}}$ films changed from CdTe to CdS side as the concentration of CdS increased in the films. For the cubic phase of the CdTe-CdS alloy system, the mole fraction, $\mathrm{x}$ according to Vegard's law is given by [9]:

$$
x=\frac{a_{C d S_{x} T e_{1-x}}-a_{C d T e}}{a_{C d S}-a_{C d T e}}
$$

For the mixed $\mathrm{CdS}_{\mathrm{x}} \mathrm{Te}_{1-\mathrm{x}}$ crystal, Ohata et al. [25] have reported that $\mathrm{CdS}_{\mathrm{x}} \mathrm{Te}_{1-\mathrm{x}}$ exists in cubic phase for $\mathrm{x}=0$ to $\mathrm{x} \sim 0.2$ and the lattice constant in this range varies according to Vegard's law as

$$
a(\text { zinc blend })=6.477-0.657 x
$$

But it must be taken into account that the accuracy of using XRD is limited, because the XRD signal is dominated by the layer composition closest to the surface as well as the crystallinity of the phase.

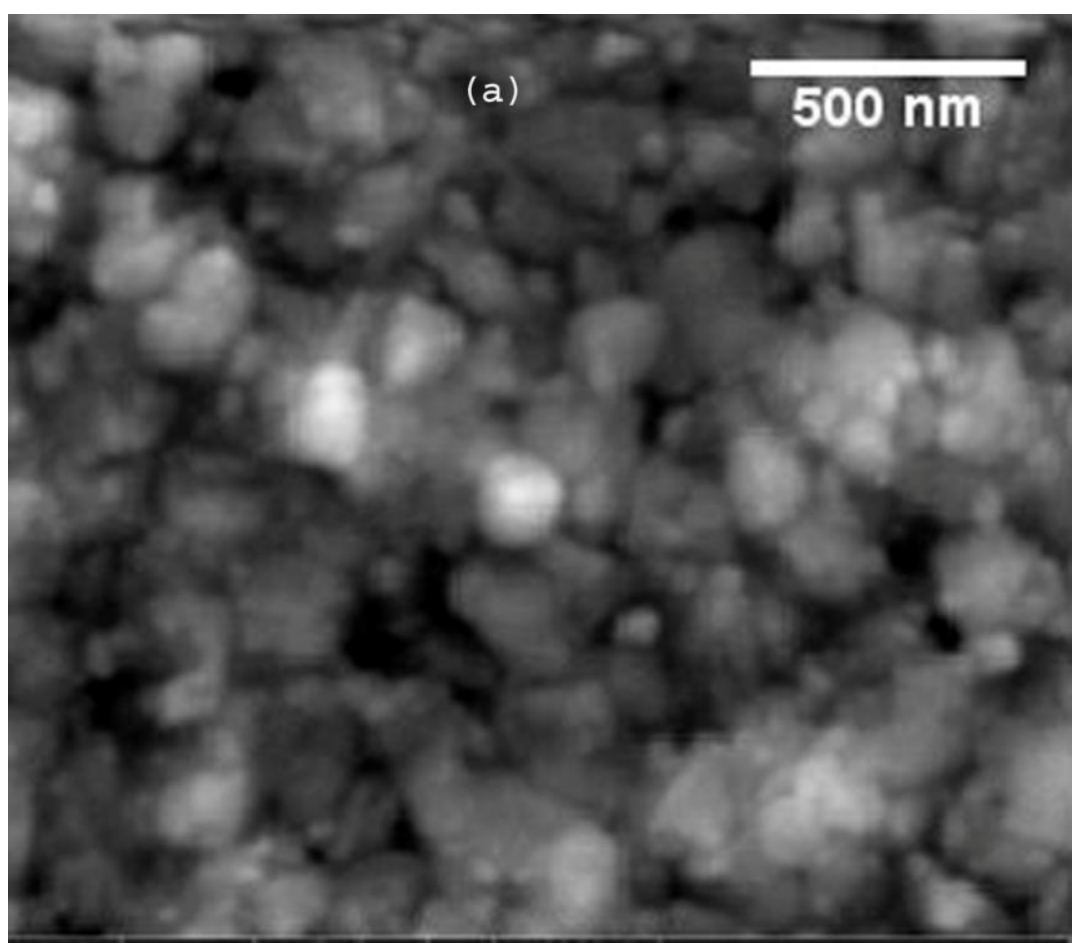




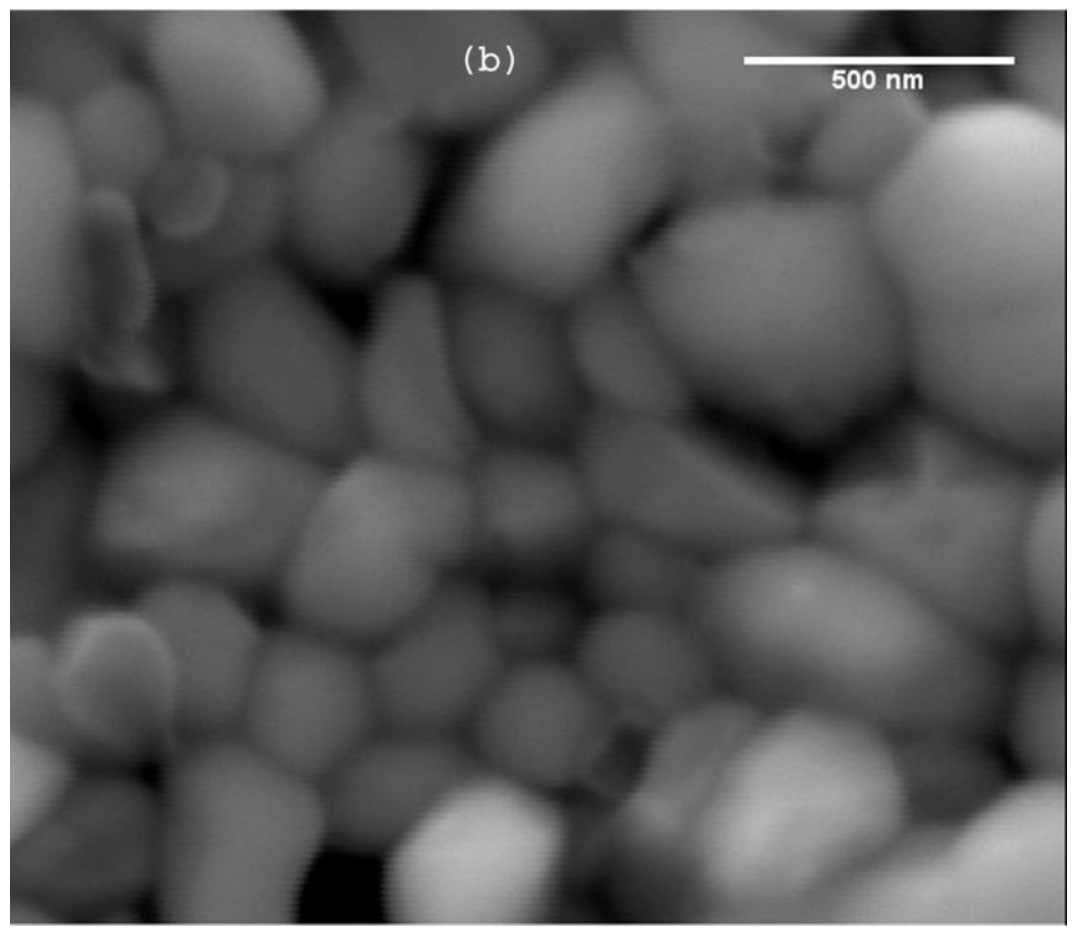

Figure 3. SEM images of two CdS $S_{1-y} T e_{y}$ films with comparable thickness and different values of y. a) $y=$ $4.51 \times 10^{-2}, t=720 \mathrm{~nm}$. b) $y=28.45 \times 10^{-2}, t=620 \mathrm{~nm}$.

Fig.3 displays the scanning electron microscope observations for another two films with comparable thickness but different Te concentration $(\mathrm{t}=720$ and $620 \mathrm{~nm}$ with $\mathrm{y}=4.51 \times 10-2$ and $28.45 \times 10-2$ respectively), where the concentrations of $\mathrm{Cd}, \mathrm{S}$ and $\mathrm{Te}$ in the films were taken from the $\mathrm{X}$-ray energy dispersive spectroscopy (EDS). The films appear to be polycrystalline and the film with higher Te concentration (Fig.3b) appears with much larger grain size despite the fact that it is thinner.

\section{Optical Properties}

\section{Bandgap Bowing}

Intermixing at the CdS/CdTe junction results with a graded region in which the bandgap depends on composition. Following the model used by Ohata et al. [25] and Pal et al. [26], the bandgap of the $\mathrm{CdS}_{\mathrm{x}} \mathrm{Te}_{1-\mathrm{x}}$ alloy can be predicted using a simple quadratic equation

$$
E_{g(\text { alloy })}=k x^{2}+\left(E_{g(C d S)}-E_{g(C d T e)}-k\right) x+E_{g(C d T e)}
$$

Hence the bandgap of the $\mathrm{CdS}_{1-\mathrm{y}} \mathrm{Te}_{\mathrm{y}}$ alloy will be given by

$$
E_{g(\text { alloy })}=k x^{2}+\left(E_{g(C d T e)}-E_{g(C d S)}-k\right) x+E_{g(C d S)}
$$

where $k$ is the bowing parameter and its theoretical value is 2.0 [26].

Several experimental results are consistent with Eq. [3] for $\mathrm{CdS}_{\mathrm{x}} \mathrm{Te}_{1-\mathrm{x}}[9,12,27]$, but according to our knowledge, there are no experimental or theoretical results for $\mathrm{CdS}_{1-\mathrm{y}} \mathrm{Te}_{\mathrm{y}}$. For $\mathrm{CdS}_{\mathrm{x}} \mathrm{Te}_{1-\mathrm{x}}$ alloy, Duenow et al. [9] found that the bandgap decreases below the CdTe bandgap value of $\mathrm{E}_{\mathrm{g}(\mathrm{cdTe})}=1.5 \mathrm{eV}$, to as low as $1.41 \mathrm{eV}$ at $\mathrm{x} \sim 0.3$, before increasing at higher $\mathrm{x}$ values. Ohata et al. [27] have shown that the bandgap of $\mathrm{CdS}_{\mathrm{x}} \mathrm{Te}_{1-\mathrm{x}}$ alloy decreases with addition of $\mathrm{S}$ in the Te-rich region for values of $\mathrm{x}$ up to 0.25 . In addition, Murali et al. [12] observed that the bandgap shifts towards CdS side as the concentration of 
$\mathrm{CdS}$ in the films increases, and got a bandgap that varies from 1.44 to $2.41 \mathrm{eV}$ as the percentage of CdS increased. On the other hand, for $\mathrm{CdS}_{\mathrm{x}} \mathrm{Te}_{1-\mathrm{x}}$ nanocrystalline thin films, Marymathelane et al. [10] got $\mathrm{E}_{\mathrm{g}}$ values in the range of $1.54-2.32 \mathrm{eV}$ for films of different composition and observed that the bandgap shifts towards CdS side as the concentration of CdS in the films increases, which may mean that they did not got quadratic relation between $\mathrm{E}_{\mathrm{g}}$ and $\mathrm{x}$.

As mentioned in sub-section 2.1, the alloy system also exhibits a miscibility gap (two-phase region) in which both a Te-rich ZB phase and S-rich WZ phase may be present simultaneously at equilibrium. The composition of each phase in the two-phase region is the same as in the corresponding single-phase regions at the edges of the miscibility gap, with the relative quantity of each phase present varying with $x$ [9]. Single-phase films, however, have been grown within the miscibility gap; implying nonequilibrium growth methods were used. The phases generally separated after a $\mathrm{CdCl}_{2}$ heat treatment [9]. The miscibility gap in CdS-CdTe system limits the range of alloy compositions in the intermixed region [4].

\section{Photoluminescence}

Fig.4 displays the photoluminescence spectra of the three CdS1-yTey thin films mentioned in subsection 2.1 which are prepared by Ikhmayies and Ahmad-Bitar [21] measured at $60 \mathrm{~K}$ taken by two gratings of different ranges (the first grating has a range: $640-1280 \mathrm{~nm}$ and the second grating has a range: $190-860 \mathrm{~nm}$ ). From the figure it is noticed that, first in the high energy part (Fig.4a), the weakest PL signal is that of film (a) and the strongest one is that of film (c). In the low energy part (Fig.4b) the opposite is found; that is the strongest PL signal is that of film (a) and the weakest is that of film (c). This is because film (a) has the larger Te content and film (c) has the smaller Te content -not measured but known from annealing time in Te vapor and color of the film. That is the shift of the PL spectra becomes deeper into the lower energy side as the concentration of Te increases, which is a result of the alloying of the CdS with Te. Peak-broadening observed in all PL spectra in Fig.4 is due to the superposition of spectra corresponding to the range of crystallites' sizes present in the alloyed layer, because the films contain particles of different sizes as seen in the SEM micrographs shown in Fig.3.

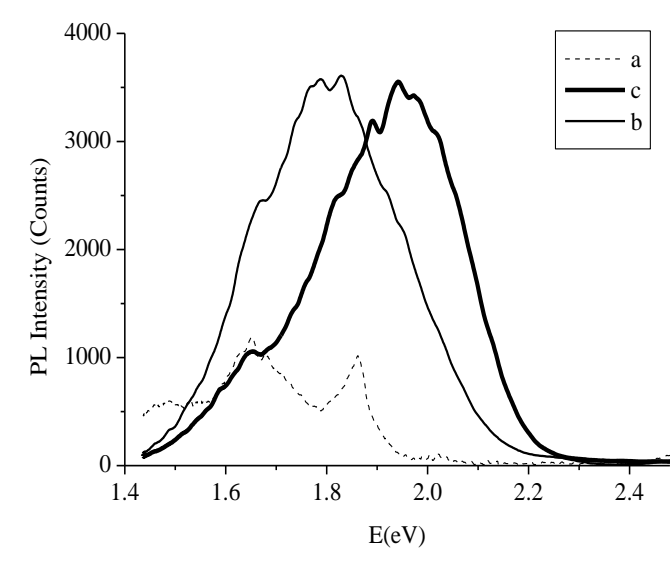

(a)

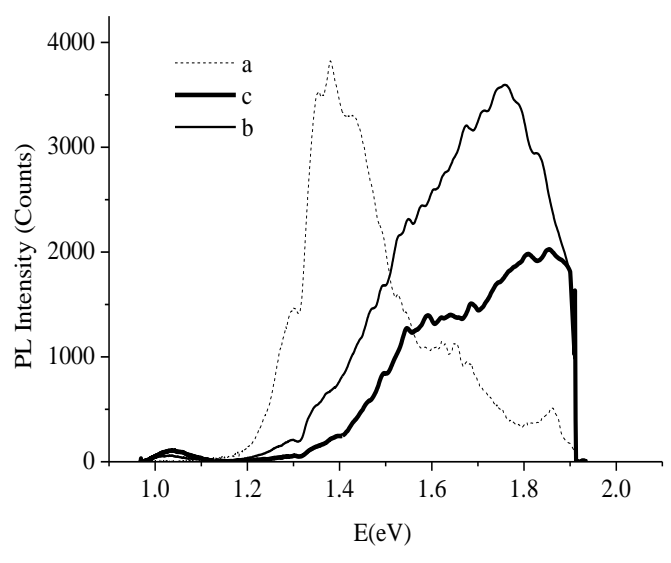

(b)

Figure 4. The photoluminescence spectra of $C d S_{1-y} T e_{y}$ thin films measured at $60 \mathrm{~K}$. a) Taken by the second grating. b) Taken by the first grating [21]. 


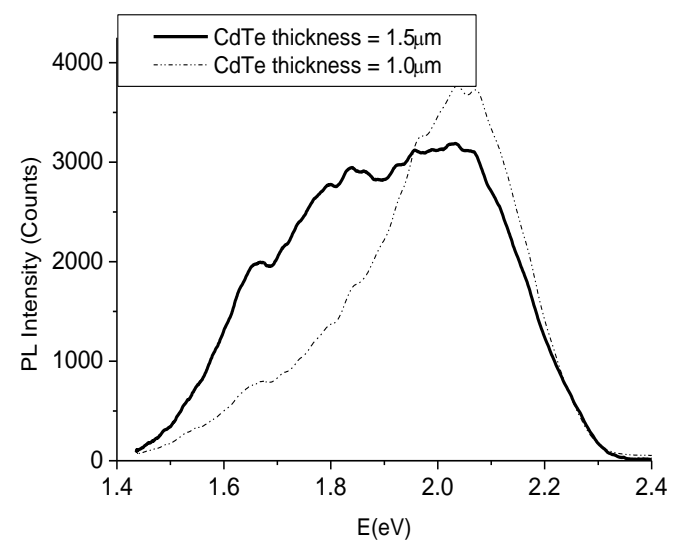

(a)

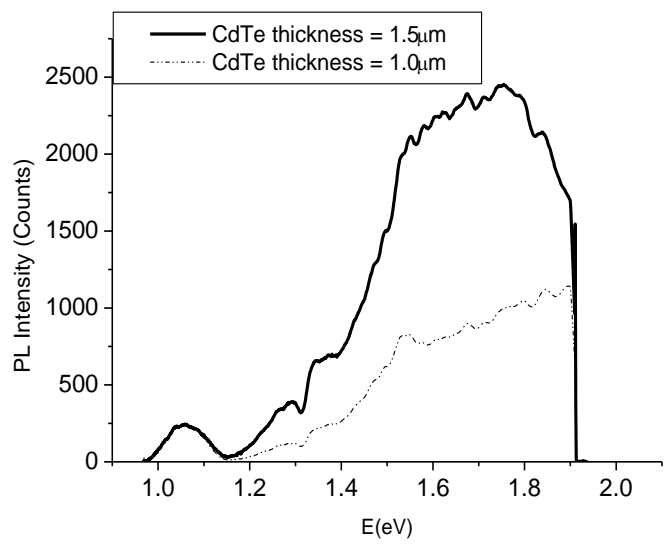

(b)

Figure 5. The photoluminescence spectra of the interface of CdS/CdTe solar cells. a) taken by the second grating. b) taken by the first grating [28].

Fig.5 displays the PL spectra of the interfacial region of the CdS/CdTe solar cells -from the glass sideafter $\mathrm{CdCl} 2$ heat treatment [28], where there is no luminescence from the CdTe side. The figure shows the PL spectra for two solar cells with similar SnO2:F and CdS:In thickness $(200 \mathrm{~nm}$ and $500 \mathrm{~nm}$ respectively), but different thickness of the CdTe layer. The PL spectra in Fig. 5a were recorded by the second grating, and that in Fig. $5 \mathrm{~b}$ were recorded by the first one. The thickness of the CdTe layer is 1.0 $\mu \mathrm{m}$ in one solar cell, and $1.5 \mu \mathrm{m}$ in the other. It is obvious that these curves are largely identical to the PL spectra of the CdS1-yTey thin films shown in Fig.4. These results confirm that these PL spectra are from the CdS1-yTey solid solution in the interfacial region of the solar cell, since as mentioned before the CdTe layer has no luminescence. The same observations found in Fig.4 are present in Fig.5. That is, first, the PL spectrum of the thicker cell has a deeper shift to the lower energy side. Second, the broadest spectrum (largest bandwidth) is that of the thicker cell. The main peaks in the solar cells' spectra are far from the bandgap energy of CdTe $(1.5 \mathrm{eV})$, but closer to the bandgap energy of CdS:In $(2.5 \mathrm{eV})$, especially those of the thinner cell.

\section{THE SIGNIFICANCE OF CdS $\mathrm{CT}_{1-\mathrm{x}}$ IN THE INTERFACIAL REGION OF CDS/CDTE SOLAR CELL}

The interdiffusion processes taking place at the CdS/CdTe interface during CdTe deposition at high temperature and/or $\mathrm{CdCl} 2$ heat treatment have largely been realized to significantly affect the device performance. There is $10 \%$ lattice mismatch between $\mathrm{CdS}$ and CdTe, which should generate a large density of defects [4], and produces strain at the CdS/CdTe interface [9]. Intermixing at the CdS/CdTe interface is expected to reduce the effect of lattice mismatch, and then it relieves strain, reduces the number of interfacial states, and reduces the number of recombination centers [20]. In addition, a graded layer is formed at the interface $[4,20]$ in which a gradual bandgap is produced in the interfacial region. As explained in sub-section 2.2.1, this bandgap varies with composition $\mathrm{x}$ according to quadratic relations Eq.(2) and Eq.(3) due to the optical bowing parameter of the CdTe-CdS alloy system. This results in a narrowing of the absorber-layer bandgap, and hence a higher long wavelength quantum efficiency of the solar cell. Intermixing at the $\mathrm{CdS} / \mathrm{CdTe}$ interface also passivates (at least partially) the grain boundaries and improves the carrier lifetime in the absorber, and it may reduce the dark recombination current. 


\section{CONTROLLING CdS/CdTe INTERDIFFUSION}

In CdS/CdTe thin film solar cells, alloy formation has both beneficial and detrimental effects on device performance depending on how the alloys are formed, their composition and their compositional distribution. The proper amount of interdiffusion is necessary for a superior efficiency solar cell [8]. However, diffusion of CdS into CdTe is a faster process than that of CdTe into CdS, and is more difficult to control, especially for cell structures with ultra-thin, $<100 \mathrm{~nm}, \mathrm{CdS}$ films. Diffusion of CdTe into CdS has unwanted effects: It can reduce the transmissive properties of the window, and the CdS film thickness will be reduced, which can be beneficial for window transmission, but can result in lateral junction discontinuities. Non-uniform consumption of $\mathrm{CdS}$ can be mitigated by heat treatment of the $\mathrm{CdS}$ layer prior to CdTe deposition to increase CdS grain size, density, sharpen the CdS optical transmission edge, and to form oxides, which reside on grain surfaces and penetrate grain boundaries. In this case, $\mathrm{CdS}$ consumption can be limited by reducing grain boundary diffusion, $\mathrm{CdCl} 2$ and $\mathrm{O} 2$ vapor concentrations and treatment temperature.

A viable processing route that can be established for minimizing CdS consumption and deterioration of the device performance is utilizing uniform CdTe1-xSx alloy absorber layers in place of pure CdTe $[7,29,30]$ to prevent deterioration of the solar cell related to interdiffusion and current losses. But it is found that this directly-deposited alloy layer is not fundamentally detrimental to device performance [19]. Duenow et al. [29] found that devices that received no $\mathrm{CdCl} 2$ treatment performed poorly, while devices containing the alloy layer that received a $\mathrm{CdCl} 2 \mathrm{HT}$ after the CdTe deposition in many cases showed comparable performance to devices without the alloy layer.

\section{CONCLUSIONS}

The CdSxTe1-x solid solution usually forms due to interdiffusion between CdS and CdTe in the interfacial region of the $\mathrm{CdS} / \mathrm{CdTe}$ solar cell during the deposition of CdTe layer at high temperature and/or $\mathrm{CdCl} 2$ heat treatment. It also can be produced in the form of thin films by several methods. The Te rich CdSxTe1-x has a cubic structure, the S rich CdS1-yTey has a hexagonal structure, and there is a miscibility region in which both phases are found. Cubic CdSxTe1-x has crucial role in improving the performance of the solar cell because it reduces $\mathrm{CdS} / \mathrm{CdTe}$ lattice mismatch and increases the quantum efficiency due to bandgap bowing. It is necessary to control intermixing at the interface to prevent the non uniform consumption of the $\mathrm{CdS}$ window layer.

\section{REFERENCES}

[1] Potter, MDG, Cousins, M, Durose, K., and Halliday, DP. Effect of interdiffusion and impurities on thin film $\mathrm{CdTe} / \mathrm{CdS}$ photovoltaic junctions. Journal of Materials Science: Materials in Electronics 2000; 11: 525-530. https://doi.org/10.1023/A:1026565632569

[2] Safa Sultana, R, Bahar, AN, Asaduzzaman, M, and Ahmed, K. Numerical modeling of a CdS/CdTe photovoltaic cell based on ZnTe BSF layer with optimum thickness of absorber layer. Cogent Engineering 2017; 4: 1318459. https://doi.org/10.1080/23311916.2017.1318459 
[3] Kuciauskas, D, Kanevce, A, Duenow, JN, Dippo, P, Young, M, Li, JV, Levi, DH, and Gessert,TA. Spectrally and time resolved photoluminescence analysis of the $\mathrm{CdS} / \mathrm{CdTe}$ interface in thin-film photovoltaic solar cells. Applied Physics Letters 2013; 102: 173902. https://doi.org/10.1063/1.4803911

[4] Dhere, R, Wu, X, Albin, D, Perkins, C, Moutinho, H, and Gessert, T. Formation and characterization of $\mathrm{CdS}_{\mathrm{x}} \mathrm{Te}_{1-\mathrm{x}}$ alloys prepared from thin film couples of $\mathrm{CdS}$ and CdTe. Presented at the $29^{\text {th }}$ IEEE PV Specialists Conference; May 20-24, 2002: New Orleans, Louisiana. NREL/CP-520-31435

[5] Dhere, R, Rose, D, Albin, D, Asher, S, Al-Jassim, M, Cheong, H, Swartzlander, A, Moutinho, H, Coutts, T, and Sheldon, P. Influence of CdS/CdTe interface properties on the device properties. Presented at the $26^{\text {th }}$ IEEE Photovoltaic Specialists Conference; September 29-October 3, 1997: Anaheim, California. NREL/CP520-22947.

[6] Ikhmayies, SJ. S-Rich $\mathrm{CdS}_{1-\mathrm{y}} \mathrm{Te}_{\mathrm{y}}$ Thin Films Produced by the Spray Pyrolysis Technique. Energies 2016; 9: Article ID. 234. doi:10.3390/en9040234.

[7] Gordillo, G, Rojas, F, and Calderón, C. Optical characterization of $\mathrm{Cd}\left(\mathrm{S}_{\mathrm{x}}, \mathrm{Te}_{1-\mathrm{x}}\right)$ thin films deposited by evaporation. Superficies y Vasio 2003; 16 (3): 30-33.

[8] Kale, M, Bhavsar, D. Synthesis and characterization of nanostructured $(\mathrm{CdS})_{0.8} \mathrm{Te}_{0.2}$ thin films for solar cell application. International Journal of Engineering Sciences \& Research Technology 2014; 3(4) : 7012-7015.

[9] Duenow, JN, Dhere, RG, Moutinho, HR, To, B, Pankow, JW, Kuciauskas, D, and Gessert, TA. CdS $\mathrm{x}_{\mathrm{x}} \mathrm{Te}_{1-\mathrm{x}}$ alloying in CdS/CdTe solar cells. Presented at the 2011 Materials Research Society Spring Meeting ; April 25-29, 2011 : San Francisco, California.

[10] Marymathelane, R, Ritajohn, Murali, KR. Optical properties of $\mathrm{CdS}_{\mathrm{x}} \mathrm{Te}_{1-\mathrm{x}}$ nanocrystalline thin films, The International Journal Of Engineering And Science (Ijes) 2013 ; 2(3) : 14-18.

[11] Compaan, AD, and Bohn, RG. High-efficiency thin-film cadmium telluride photovoltaic cells. Final Technical Report; 31 January 1994-31 March 1998: Contract No. ZAX-4-14013-4.

[12] Murali, KR, Thirumoorthy P, Kannan, C, Sengodan, V. Pulse plated $\mathrm{CdS}_{\mathrm{x}} \mathrm{Te}_{1-\mathrm{x}}$ films and their properties. Solar Energy 2009; 83: 14-20. doi:10.1016/j.solener.2008.06.006

[13] Kale, MS, Toda, YR, Bhavsar, DS. Synthesis and characterization of nanocrystalline $(\mathrm{CdS})_{0.6} \mathrm{Te}_{0.4}$ thin films deposited by closed space sublimation technique. IOSR Journal of Applied Physics (IOSR-JAP) 2014, 6(2) : 22-27.

[14] Gaewdang, T, and Wongcharoen, N. Physical properties of $\mathrm{CdS}_{\mathrm{x}} \mathrm{Te}_{1-\mathrm{x}}$ thin films prepared by close spaced sublimation method. Materials Science Forum 2017; 890: 291-294. DOI: 10.4028/www.scientific.net/MSF.890.291

[15] Jácome, C, Flórez, M, Gurevich, YG, Giraldo, J, and Gordillo, G. Characterization of $\mathrm{CdS}_{\mathrm{x}} \mathrm{Te}_{1-\mathrm{x}}$ thin films through thermoelectric power measurements. Journal of Physics D: Applied Physics 2001; 34 (12): Article ID. 1862. DOI: https://doi.org/10.1088/0022-3727/34/12/315

[16] Kosyachenko, L, Lashkarev, G, Grushko, E, Ievtushenko, A, Sklyarchuk, V, Mathew, X, and Paulson, PD. Spectral distribution of photoelectric efficiency of thin-film CdS/CdTe heterostructure. Acta Physica Polonica A 2009; 116: 862-864.

[17] Narayanswamy, C, Gessert, TA, Asher, SE. Analysis of Cu diffusion in ZnTe-based contacts for thin-film CdS/CdTe solar cells. AIP Conference Proceedings 1999; 462 (1): 248. https://doi.org/10.1063/1.57902

[18] Proskuryakov, YY, Durose, K, Al Turkestani, MK., Mora-Sero, I, Garcia-Belmonte, G, Fabregat-Santiago, F, Bisquert, J, Barrioz, V, Lamb, D, Irvine, SJC, and Jones, EW. Impedance spectroscopy of thin-film $\mathrm{CdTe} / \mathrm{CdS}$ solar cells under varied illumination. Journal of Applied Physics 2009; 106: 044507. DOI: https://doi.org/10.1063/1.3204484

[19] Oladeji, IO, Chow, L, Liu, JR., Chu, WK., Bustamante, ANP, Fredricksen, C, and Schulte, AF. Comparative study of CdS thin films deposited by single, continuous, and multiple dip chemical processes. Thin Solid Films 2000; 359: 154-159. DOI: https://doi.org/10.1016/S0040-6090(99)00747-6

[20] Ikhmayies, SJ, and Ahmad-Bitar, RN. $\mathrm{CdS}_{1-\mathrm{y}} \mathrm{Te}_{\mathrm{y}}$ thin films: Production and bandgap investigation. Solar Energy 2012; 86 (9): 2613-2619. DOI: https://doi.org/10.1016/j.solener.2012.05.032

[21] Ikhmayies, SJ, and Ahmad-Bitar, RN. Photoluminescence and transmittance of $\mathrm{CdS}_{1-\mathrm{x}} \mathrm{Te}_{\mathrm{x}}$ thin films. $J$. Luminouscence 2012; 132: 2826-2831. DOI: https://doi.org/10.1016/j.jlumin.2012.06.011

[22] Ikhmayies, SJ. Optical parameters of spray-deposited $\mathrm{CdS}_{1-\mathrm{y}} \mathrm{Te}_{\mathrm{y}}$ thin films. JOM 2017; 69 (2): 191-197. DOI: https://doi.org/10.1007/s11837-016-2199-0

[23] Ameri, M, Mesbah, S, Al-Douri, Y, Bouhafs, B, Varshney, D, and Ameri, I. First-Principles Calculations of Structural, Electronic, Optical, and Thermodynamic Properties of CdS, CdTe and Their Ternary Alloys CdS $\mathrm{C}_{1-}$ ${ }_{\mathrm{x}} \mathrm{Te}_{\mathrm{x}}(0.0 \leq \mathrm{x} \leq 1.0)$, Acta Physica Polonica A 2014; 125: 1110-1117. DOI: 10.12693/APhysPolA.125.1110

[24] Murali, KR, and Thirumoorthy, P. Photoelectrochemical properties of $\mathrm{CdS}_{\mathrm{x}} \mathrm{Te}_{1-\mathrm{x}}$ films, Chalcogenide Letters $2009 ; 6(8): 377-384$

[25] K. Ohata, J. Saraie, T. Tanaka, Optical energy gap of the mixed crystal $\mathrm{CdS}_{x} \mathrm{Te}_{1-x}$, Jpn. J. Appl. Phys. 1973; 12(10): Article ID. 1641. DOI: https://doi.org/10.1143/JJAP.12.1641 
[26] Pal, R, Dutta, J, Chaudhri, S, and Pal, AK. CdS $\mathrm{Te}_{1-\mathrm{x}}$ films: preparation and properties. J. Phys. D: Appl.Phys. 1993; 26: 704-710.

[27] Ohata, Saraie, K., J, and Tanaka, T. Phase diagram of the CdS-CdTe pseudobinary system. Jap. J. of Appl.Phys. 1973; 12(8): 1198-1204. DOI: https://doi.org/10.1143/JJAP.12.1198

[28] Ikhmayies, SJ, and Ahmad-Bitar, RN. Interface photoluminescence of the $\mathrm{SnO}_{2}: \mathrm{F} / \mathrm{CdS}: \mathrm{In} / \mathrm{CdTe}$ thin film solar cells prepared partially by the spray pyrolysis technique. J. Luminouscence 2012; 132: 502-506. DOI: https://doi.org/10.1016/j.jlumin.2011.09.030

[29] Duenow, JN, Dhere, RG, Moutinho HR, To B, Pankow, JW, Kuciauskas, D, and Gessert, TA. CdS/CdTe solar cells containing directly deposited $\mathrm{CdS}_{\mathrm{x}} \mathrm{Te}_{1-\mathrm{x}}$ alloy layers, Presented at the $37^{\text {th }}$ IEEE Photovoltaic Specialists Conference (PVSC 37); June 19-24, 2011: Seattle, Washington.

[30] McCandless, BE, and Birkmire, RW. Influence of window and absorber layer processing on device operation in superstrate thin film CdTe solar cells. Presented at the Photovoltaic Specialists Conference 2000. Conference Record of the Twenty-Eighth IEEE; 15-22 Sept. 2000: Anchorage, AK, 491-494. DOI: 10.1109/PVSC.2000.915879. 